\title{
INTRODUCTION TO THE SPECIAL ISSUE: CATALAN PHILOSOPHY IN THE MIDDLE AGES
}

\author{
Mario Macías (iD \\ (Institute of Law and Technology, Universitat Autònoma de Barcelona) \\ mario.macias@uab.cat \\ Pere Ripoll \\ (Universitat Pompeu Fabra) \\ pere.ripoll@upf.edu
}

\begin{abstract}
Acknowledgements: Project IEC PRO2018-S05. Models del dret i la filosofia política catalanes: semàntica de les doctrines juridicopolítiques del pactisme en les seves diferents fases [Models of Catalan political philosophy and law: Semantics of pactmodel driven political and legal doctrines at their different stages].

Disclosure statement: No potential conflict of interest was reported by the authors.

License: This work is under Attribution-NonCommercial-ShareAlike 4.0 International (CC BY-NC-SA 4.0) https://creativecommons.org/licenses/by-nc-sa/4.0/

Suggested citation: Macías, M., Ripoll, P. (2019-2020). "Introduction to the Special Issue: Catalan Philosophy in the Middle Ages”, Journal of Catalan Intellectual History, 12: 4-7 DOI: 10.2478/jocih-2019-0011
\end{abstract}

C2021, Journal of Catalan Intellectual History

This Special Issue can hardly be considered a monography, at least in the classical sense. The contributions that inform this volume cover a wide range of topics from a wide range of perspectives, methodologies and backgrounds. Although they all are linked by the temporal scope of the Middle Ages, there is only one overarching notion which underpins all of them: agreement. This concept is an old friend to political and legal philosophy. It has been discussed and interpreted in many different apparently disconnected ways, periods and traditions. It can be found as an elemental instrument for doctrinal legitimation at the bases of an endless number of theories and models of authority.

Catalan legal and political history owes much to the idea of agreement. From the earlier convenientiae and assemblies of peace and truce in the tenth century to the refinement of Catalan parliamentarism at the dawn of the modern period, pactisme molded the foundations of public and private relations. But pactisme, the tendency towards negotiation and pact making, did not emerge as a reasoned and conscious ideology - it came much later. It originally appeared as the only instinctive solution to overcome the mayhem thefirst feudalism had brought about. Since the thirteenth century - once the bases of statehood had been set-, the weakness of the CatalanAragonese monarchy, the influence of the nobility and ecclesiastical lords, and the economic 
weight of the new-born urban bourgeoisie hampered the monopolization of power. Political actors were almost compelled to reach agreements to ensure the functioning of the realm. In other words, pactisme set a balance between the social powers. Beyond formal hierarchies, political mysticism and the prompt development of positive rules (the Usatges), Catalonia was a clear example of medieval legal realism. The divine right of the king to rule over his subjects was virtually a mere theoretical fiction if he could not count on their consent.

The Corts, the representative assembly of the three orders, became the highest expression of the pact-based nature of the Catalan legal system. The monarchs themselves remained subordinated to it, whereas the principle of the empire of law (imperium) became a fundamental pillar of the medieval and modern political architecture of Catalonia. This constitutional design means that Catalonia was structured through a dualistic monarchy: on one hand, the general community was represented at its highest level by the prince; on the other hand, by the representative bodies of the Principality. These bodies were composed of the estates (nobility, church and royal municipalities) within the said Corts and its executive arm, the Generalitat. This second institution became the greatest guarantor of the autonomy of the estates and played a fundamental role in the defense of political dualism and legal pactisme.

This dimension led to the formation of a permanent political space impossible to dismantle. The early compilations of Corts' sessions and decisions-such as the Llibre de Vuit Senyals (LVS) - contributed to ensure this continuity. They became an instrument for reaffirming the institutional autonomy of the estates before the monarchy. The legal terminology of these texts is illustrative of the synallagmatic relationship between the king and the estates. Certain prerogatives and powers of the estates can be considered anti-absolutist measures, limiting the plenitudo potestatis. They also gave access to the estates to privileges traditionally reserved to the monarch, a characteristic attribute of pactisme.

However, pactisme was not limited to the institutional and legal domain. It irradiated to all aspects of social and private life. Catalonia, especially the urban areas, was a territory open to the cultural diversity of the Mediterranean, to its peoples, trade and conflicts. There were also important native clusters of Jews and Muslims, who were grouped in autonomous and self-managed communities. Though marginalized from the Christian body (Corpus Mysticum), they were not isolated, and interactions with their neighbors were constant. Thus, the pact was the social driver that ensured coexistence. A coexistence which, nevertheless, progressively deteriorated in the last centuries of the Middle Ages.

This forced balance was not harmonious. It was not a utopia of mutual understanding and democracy. The specter of violence haunted Catalan society in every corner. In fact, violence laid down the foundations for pactisme and was integrated into this system. Its institutionalization via vindictive law and private wars, for example, turned it into a purifying instrument to relieve social tensions. As historians like Johan Huizinga have evinced, the medieval mind was not a restrained one. Despite passions belonged to strict and immovable social codes, they were expressed with total fervor. Anger, happiness, sorrow and piety were hyperbolically and violently manifested. Thus, violence needed to be channeled somehow. But the system was imperfect, and the equilibrium was often broken: disorders, uprisings and civil conflicts arose when pactisme failed. 
Pactisme was, therefore, present in political institutions, in legal procedures, in the relationships between feudal orders, in the family sphere, in the marketplace and eventually wherever social interactions took place. It was not-particularly in its legal and political dimension-a monolithic construction. Indeed, there were many pactismes in Medieval Catalonia. Jewish communities (qehillot, "קהילות") for example, built on pact-based self- government systems to replace the absence of legitimated central authorities. Simultaneously, the qehillot were influenced by the surrounding institutional models - cultural blending and acculturation were inescapable phenomena. Complementing this inner panorama, the Catalan-Aragonese Crown developed an active foreign policy and kept close contacts with other political systems. In addition, the Church played a leading configurative role via its rules, canonists, and universities - which were attended by a large number of Catalan legal experts (the case of Ramon of Penyafort is paradigmatic).

While the pactisme was instinctively born, it soon became a subject of doctrinal discussion and development. Already in the fourteenth century, authors like Ramon Saera (d. 1357) and Francesc Eiximenis (1330-1409) reflected on the nature and ins-and-outs of this system. They were followed by a rich concatenation of authors who evince the complex and progressive evolution of the different dimensions of pactisme, agreement and dialogue, and their later contacts with humanism-Pere Belluga (1392-1468), Tomàs Mieres (1400-1474), Joan Lluís Vives (14921540), Lluís de Peguera (1540-1610), etc. Each one of them of diverse origins, condition, and territory. We should underline the plural and composite nature of the individual polities, cultures and languages of the Crown of Aragon - Catalonia, Valence, Majorca...

Christian theology largely contributed to this process of political construction. It provided legal instruments (ius commune), but also a spiritual ethos. The Catalan system emerged and evolved as a result of contextual requirements. Nevertheless, its legitimation was intrinsically bound to the Christian ideal of political community. The earthly kingdom must reflect the Kingdom of Heaven - the Augustinian Civitas Dei. Accomplishing this holy symmetry was the ultimate target of medieval political theology, from Augustine of Hippo (d. 430) to Dante Alighieri (d. 1321). Francesc Eiximenis linked both realities - agreements and eschatology - in the twelfth book of Lo Crestià:

(...) Nostre senyor Déu (...) sí li ha dada natural inclinació [to man] de viure en companyia béarreglada e bé endreçada segons l'esperit e lo cos, que sia apellada ciutat material, e per tal que, atenenta aquesta material ciutat, conegués la ciutat espiritual que porta absi $(\ldots)^{l}$.

Even the apologetic works of thirteenth-century Catalan theologians (especially Ramon Llull and Ramon Martí) addressed the idea of agreement as a missionizing instrument. The infidel can be defeated in battle (Crusade), but he must be converted with love and wisdom. The dialectic approach to conversion that flourished in the period implied that Christianism could be logi-

\footnotetext{
1 "God our Lord has bestowed upon [man] a natural inclination to live in good and organized company according to the soul and body. This is the so-called earthly city. Taking care of his earthly city he thereby will know the heavenly city that his soul bears (...)". Our translation from Eiximenis, F. 2009. Lo regiment de la cosa pública en el Dotzè del Crestià. Madrid: Centro de Lingüística Aplicada Atenea, p. 70.
} 
cally demonstrated - and, therefore, Judaism and Islam could be logically refuted. The organization of theological disputations between Christian and non-Christian men of faith opened the door to a new dimension of dialogue. These debates enabled an unprecedented degree of cross- cultural interaction and bolstered a wave of Latin translations of Jewish and Muslim sources. It is even possible to speak of a certain cultural blending-Arnau de Vilanova's Allocutio super Tetragrammaton is a clear example. However, the new apologetics also traced a thin and blurred border between coexistence and violence: if the enemy knows the (Christian) truth and he does not accept it because of his perfidy, he must be eliminated.

This eclecticism and potential diversity of scopes turns this Special Issue into a monographic volume. In it, the authors explore and offer different perspectives on the construction of pactisme beyond its mere political and legal development in Catalan institutions. The insights into the Jewish and Islamic counterparts, as well as into the cultural interactions, provide an overall picture of its multifaceted complexity.

The current volume is a result of the meetings and academic discussions held in the context of the project El diàleg com a font de dret. Modelització dels fonaments de la filosofia política i jurídica catalana (s. XII-XXI), funded by the Institut d'Estudis Catalans (IEC). The purpose of this project is to analyze the process of construction of legal pactisme through the use of techniques that range from Natural Language processing (NLP), corpus linguistics, statistical clustering, automatic content analysis, and ontologies to Catalan philosophical, political and legal texts. The multidisciplinary character of the research team - which is composedby philosophers, legal historians, computational scientists, experts on discourse analysis, etc.- - aims to ensure a comprehensive approach to this process. 